\title{
Combining glucose and sodium acetate improves the growth of Neochloris oleoabundans under mixotrophic conditions
}

\author{
Helder Rodrigues Silva ${ }^{1,4}$, Cassio Egidio Cavenaghi Prete ${ }^{1}$, Freddy Zambrano 1,4 ${ }^{1,}$ Victor Hugo de Mello ${ }^{4,3}$, \\ Cesar Augusto Tischer ${ }^{2}$ and Diva Souza Andrade ${ }^{4^{*}}$
}

\begin{abstract}
Mixotrophic cultivation is a potential approach to produce microalgal biomass that can be used as raw materials for renewable biofuels and animal feed, although using a suitable, cost-effective organic carbon source is crucial. Here, we used a Box-Behnken design with three factors, the glucose and sodium acetate concentrations, and the percentage of Bold's basal medium (BBM), to evaluate the effects of different carbon sources on biomass productivity and the protein and lipid contents of Neochloris oleoabundans (UTEX\#1185). When grow at optimal levels of these factors, $100 \%$ BBM plus $7.5 \mathrm{~g} \mathrm{~L}^{-1}$ each of glucose and sodium acetate, N. oleoabundans yielded $1.75 \mathrm{~g} \mathrm{~L}^{-1}$ of dry biomass, with $4.88 \pm 0.09 \% \mathrm{~N}, 24.01 \pm 0.29-30.5 \pm 0.38 \%$ protein, and $34.4 \% \pm 0.81$ lipids. A nuclear magnetic resonance spectrum ( ${ }^{1} \mathrm{H}-\mathrm{NMR}$ ) of a lipid extract showed that the free fatty acid content was $11.25 \%$. Thus, combining glucose and sodium acetate during the mixotrophic cultivation of $\mathrm{N}$. oleoabundans can yield greater amounts of biomass, proteins, and lipids for biofuel production.
\end{abstract}

Keywords: BBM dilution, Free fatty acid, Mixotrophic, Total lipid, Total protein, Response surface methodology

\section{Introduction}

Increasing use of oil-derived energy has generated negative environmental effects such as pollution and greenhouse gas emissions. To seek alternatives sources of bioenergy, several studies of the growth of photosynthetic microorganisms suggested that microalgae can be used to produce sustainable feedstocks for energy production (Amaro et al. 2011; Georgianna and Mayfield 2012; Ghosh et al. 2015; Pruvost et al. 2011; Zhang et al. 2011), including bioethanol via enzymatic hydrolysis (Kim et al. 2014) and biogas, such as biohydrogen and biomethane, from anaerobic fermentation (Wieczorek et al. 2014). Extracted oils from the biomass of some genera of microalgae have a high free fatty acid (FFA) content that can account for up to $85 \%$ of the total lipids (Chen et al. 2012; Krohn et al. 2011). Microalgal biomass

\footnotetext{
*Correspondence: diva@iapar.br

${ }^{4}$ Instituto Agronômico do Paraná, CP 480, Londrina, Paraná 86.047-902, Brazil

Full list of author information is available at the end of the article
}

storage conditions are very important factors, as they can decrease the lipid content, release organic volatile acids, and/or lead to the formation of FFAs (Alencar et al. 2010; Foree and McCarty 1970). In this regard, Chen et al. (2012) indicated that when biomass was stored at temperatures above the freezing point, the lipids, such as triacylglycerol, in microalgae can be hydrolyzed to FFAs by lipases, peroxidases, and phospholipases that are present in wet paste or contaminating microorganisms.

In addition to their great potential for bioenergy production, some species of microalgae are already used in aquaculture, the production of food supplements, and the pharmaceutical industry to extract high-value compounds (Gatenby et al. 2003), as well as in bioremediation and biofertilization. Biomolecules can be obtained as byproducts from microalgae during biofuel production, and their subsequent utilization in animal and aquaculture feed might sustain an industrial-scale cultivation system (Yaakob et al. 2014). A mixotrophic system is defined as one in which organic carbon sources, such as molasses, glucose, glycerol, sucrose, lactose, starch,

\section{Springer}


and $\mathrm{CO}_{2}$, are simultaneously assimilated by respiratory and photosynthetic metabolic pathways (Alkhamis and Qin 2015; Rai et al. 2013; Yeesang and Cheirsilp 2014). A mixotrophic system combines the advantages of phototrophic and heterotrophic cultures ( $\mathrm{Li}$ et al. 2014), and obtains energy from organic and inorganic carbon sources, as well as light. In mixotrophic cultivation, microalgal cultures produce more biomass (Babuskin et al. 2014), including higher amounts of pigments and fatty acids, than phototrophic systems (Alkhamis and Qin 2015).

It is believed that improved biomass productivity because of mixotrophy also enhances lipid and protein yields, at least for species such as Nannochloropsis oculata, Dunaliella salina, and Chlorella sorokiniana (Wan et al. 2011). Glucose is the final product of photosynthesis, and it is assumed that photosynthetic microalgae must be able to metabolize it. Thus, it is reasonable to expect that glucose metabolism is straightforward (Garcia et al. 2005). Improved culture media that contain different concentrations of glucose or sodium acetate as carbon sources have been analyzed extensively for microalgae cultivation (Estévez-Landazábal et al. 2013; Huang et al. 2010; Jeon et al. 2006; Li et al. 2014; Moon et al. 2013; Rai et al. 2013; Wang et al. 2012; Zhang et al. 2011). However, to our knowledge, no published study has used a response surface methodology to assess the effects of these two carbon sources on microalgal growth.

The objective of this study was to evaluate a Neochloris oleoabundans strain under mixotrophic growth conditions by combining glucose and sodium acetate as carbon sources, with a focus on the production and characterization of microalgal biomass and lipids. Here, we report the rate and yield of biomass production by N. oleoabundans after 10 and 15 days of cultivation, and how they are influenced by combining various percentages of Bold's basal medium (BBM) and glucose and sodium acetate concentrations. We used a novel response surface analysis to examine the best combination of these factors to optimize the cell density and dry biomass production of $N$. oleoabundans. We also show that in a vertical photobioreactor that uses sunlight, the microalgal biomass has high lipid and protein contents, but its lipid profile has few FFAs.

\section{Materials and methods}

\section{Microalgae and growth medium conditions}

The $N$. oleoabundans UTEX\#1185 strain was purchased from the Culture Collection of Algae at the University of Texas at Austin, Austin, TX, USA, and kept in axenic liquid BBM at the Microbial Collection (IPR) of the Instituto Agronomic Institute of Paraná (IAPAR) Paraná, Brazil. Two experiments were conducted: one in the laboratory and one in an outdoor tubular photobioreactor at experimental station of the IAPAR, in the municipality of Londrina in North Paraná State, Brazil (lat. $23^{\circ} 08^{\prime} 47^{\prime \prime}$ S, long. $51^{\circ} 19^{\prime} 1^{\prime \prime} \mathrm{W}, 640 \mathrm{~m}$ a.s.l.).

For all experiments, microalgae were grown in axenic liquid $\mathrm{BBM}$ containing the following reagents $\left(\mathrm{g} \mathrm{L}^{-1}\right)$ : $\mathrm{NaNO}_{3}, 0.25 ; \mathrm{CaCl}_{2} \cdot 2 \mathrm{H}_{2} \mathrm{O}, 0.025 ; \mathrm{MgSO}_{4} \cdot 7 \mathrm{H}_{2} \mathrm{O}, 0.075$; $\mathrm{K}_{2} \mathrm{HPO}_{4}, 0.075 ; \mathrm{KH}_{2} \mathrm{PO}_{4}, 0.175 ; \mathrm{NaCl}, 0.025 ; \mathrm{C}_{10} \mathrm{H}_{12} \mathrm{~N}-$ ${ }_{2} \mathrm{Na}_{4} \mathrm{O}_{8}, 0.0498$; ferric solution $\left(\mathrm{FeSO}_{4} \cdot 7 \mathrm{H}_{2} \mathrm{O}, 0.00498\right.$; and $1 \mathrm{~mL}^{-\mathrm{L}}$ of $\mathrm{H}_{2} \mathrm{SO}_{4}$ ). The following reagents were also used $\left(\mathrm{mg} \mathrm{L}^{-1}\right): \mathrm{H}_{3} \mathrm{BO}_{3}, 11.42 ; \mathrm{ZnSO}_{4} \cdot 7 \mathrm{H}_{2} \mathrm{O}, 1.41$; $\mathrm{MnCl}_{2} \cdot 4 \mathrm{H}_{2} \mathrm{O}, 1.44 ; \mathrm{CuSO}_{4} \cdot 5 \mathrm{H}_{2} \mathrm{O}, 1.57 ; \mathrm{NaMoO}_{4} \cdot 5 \mathrm{H}_{2} \mathrm{O}$, 0.192; and $\mathrm{Co}\left(\mathrm{NO}_{3}\right)_{2} \cdot 6 \mathrm{H}_{2} \mathrm{O}, 0.045$ (Bold 1949). The BBM was modified by the addition of different concentrations of glucose $\left(\mathrm{C}_{6} \mathrm{H}_{12} \mathrm{O}_{6}\right)$ and sodium acetate $\left(\mathrm{CH}_{3} \mathrm{COONa}\right)$ as carbon sources. The $\mathrm{pH}$ of the BBM was adjusted to 9.0 with $0.1 \mathrm{M} \mathrm{KOH}$ and sterilized by autoclaving at $121^{\circ} \mathrm{C}$ and $1.5 \mathrm{~atm}$ for $30 \mathrm{~min}$.

\section{Experimental design and treatments}

The first experiment was performed with a Box-Behnken design using STATISTICA software v7.0 (Statsoft 2007), and the results were analyzed by a response surface methodology for three independent variables (the sodium acetate and glucose concentrations and the dilution ratio in BBM, which was expressed as \% BBM). The factor levels and the independent variables are presented in Table 1. In the first part of the study, 13 trials were performed with three replicates as follows: three encoded levels $(-1,0,1)$ in 13 trials and three factors $(\mathrm{A}, \mathrm{B}, \mathrm{C}$, which correspond to the concentrations of glucose and sodium acetate, and the $\%$ BBM, respectively), were analyzed (Table 2 ).

\section{Growth chamber experiment}

A microalgal inoculum was prepared by growing cells in clear glass tubes containing $100 \mathrm{~mL}$ of sterilized $\mathrm{BBM}$ at an initial $\mathrm{pH}$ of 9.0. Media that contained supplementary carbon sources according to the treatments (Table 2) were inoculated with $10 \%(\mathrm{v} / \mathrm{v})$ of a culture of a green microalgae $N$. oleoabundans strain with a density

Table 1 Level of factors, carbon sources (glucose and sodium acetate) concentrations in $\mathrm{g} \mathrm{L}^{-1}$, the dilution of medium (Bold's Basal Medium, BBM) in percentage $(\%)$ and the corresponding encoded levels $(X)$ in the BoxBehnken design

\begin{tabular}{lccr}
\hline & \multicolumn{3}{c}{ Range of levels (X) } \\
\cline { 2 - 4 } Factors & $\mathbf{- 1}$ & $\mathbf{0}$ & $\mathbf{1}$ \\
\hline A (Glucose in $\mathrm{g} \mathrm{L}^{-1}$ ) & 0 & 5 & 10 \\
B (Sodium acetate in $\mathrm{g} \mathrm{L}^{-1}$ ) & 0 & 5 & 10 \\
C (BBM in \%) & 50 & 75 & 100 \\
\hline
\end{tabular}


Table 2 Experimental design Box-Behnken for three independent variables and experimental data with 13 trials

\begin{tabular}{|c|c|c|c|c|c|c|c|}
\hline \multirow[t]{3}{*}{ Run } & \multicolumn{3}{|c|}{ Independent variables } & \multicolumn{4}{|c|}{ Dependent variables } \\
\hline & \multirow[t]{2}{*}{ Glucose } & \multirow[t]{2}{*}{ Sodium acetate $\mathrm{g} \mathrm{L}^{-1}$} & \multirow[t]{2}{*}{ BBM (\%) } & \multicolumn{2}{|l|}{$\mathrm{OD}_{670}$} & \multicolumn{2}{|c|}{ Dry biomass $\mathrm{g} \mathrm{L}^{-1}$} \\
\hline & & & & 10 day & 15 day & 10 day & 15 day \\
\hline 1 & $-1(0.0)$ & $-1(0.0)$ & $0(75)$ & 0.170 & 0.100 & 0.080 & 0.100 \\
\hline 2 & $1(10.0)$ & $-1(0.0)$ & $0(75)$ & 0.750 & 0.826 & 0.725 & 0.485 \\
\hline 3 & $-1(0.0)$ & $1(10.0)$ & $0(75)$ & 0.203 & 0.215 & 0.264 & 0.189 \\
\hline 4 & $1(10.0)$ & $1(10.0)$ & $0(75)$ & 1.422 & 1.619 & 0.921 & 1.233 \\
\hline 5 & $-1(0.0)$ & $0(5.0)$ & $-1(50)$ & 0.305 & 0.260 & 0.150 & 0.180 \\
\hline 6 & $1(10.0)$ & $0(10.0)$ & $1(50)$ & 1.549 & 1.555 & 0.962 & 1.029 \\
\hline 7 & $-1(0.0)$ & $0(5.0)$ & $1(100)$ & 0.340 & 0.304 & 0.240 & 0.200 \\
\hline 8 & $1(10.0)$ & $0(5.0)$ & $1(100)$ & 1.729 & 1.452 & 1.195 & 1.048 \\
\hline 9 & $0(5.0)$ & $-1(0.0)$ & $-1(50)$ & 0.726 & 0.699 & 0.436 & 0.456 \\
\hline 10 & $0(5.0)$ & $1(10.0)$ & $-1(50)$ & 1.423 & 1.504 & 0.911 & 0.989 \\
\hline 11 & $0(5.0)$ & $-1(0.0)$ & $1(100)$ & 1.133 & 1.047 & 0.762 & 0.636 \\
\hline 12 & $0(5.0)$ & $1(10.0)$ & $1(100)$ & 1.807 & 1.378 & 1.529 & 0.971 \\
\hline 13 & $0(5.0)$ & $0(5.0)$ & $0(75)$ & 1.677 & 1.649 & 1.223 & 1.059 \\
\hline
\end{tabular}

The optical density at $670 \mathrm{~nm}\left(\mathrm{OD}_{670}\right)$ and dry biomass determinations N. Oleoabundans were performed after 10 and 15 days of cultivation

of $1.0 \times 10^{6}$ cells $\mathrm{mL}^{-1}$. The assays were conducted in a growth chamber with a $12 \mathrm{~h}: 12 \mathrm{~h}$ light:dark photoperiod at $28.0 \pm 2.0{ }^{\circ} \mathrm{C}$ in the light phase and $22.0 \pm 2.0{ }^{\circ} \mathrm{C}$ in the dark phase. Illumination in the growth chamber was provided by white, cool fluorescent lamps in the form of tubes that were arranged in parallel with the upper part of the cultivation container. The photon flux density of photosynthetically active radiation was $100 \pm 20$ $\mu \mathrm{E} \mathrm{m} \mathrm{m}^{-2} \mathrm{~s}^{-1}$, which was measured at the surface of the flasks using a liquor porometer (INC model LI-1600).

\section{Optical density and biomass determinations}

The optical density at $670 \mathrm{~nm}\left(\mathrm{OD}_{670}\right)$ and dry biomass determinations were performed after 10 and 15 days of cultivation. The $\mathrm{OD}_{670}$ was determined using a Genesys 10 UV spectrophotometer. To determine the dry biomass, a $40-\mathrm{mL}$ aliquot was collected from each flask and centrifuged (Model Z383 HERMLE K) at 11,536 $\mathrm{g}$ for $10 \mathrm{~min}$ at $25.0^{\circ} \mathrm{C}$. The pellet was dried to a constant weight in an oven at $60{ }^{\circ} \mathrm{C}$.

\section{Photobioreactor growth conditions}

After analyzing the results of the first experiment using a response surface methodology, a second experiment was performed in closed, vertical, tubular photobioreactors that were constructed with low-density polyethylene and which contained $20 \mathrm{~L}$ of medium with air injection (Silva et al. 2014). The culture medium consisted of $100 \%$ BBM supplemented with $7.5 \mathrm{~g} \mathrm{~L}^{-1}$ glucose and $7.5 \mathrm{~g} \mathrm{~L}^{-1}$ sodium acetate. The cultivation was conducted in October 2014 in triplicate, and the $\mathrm{pH}$ of the medium was maintained at 9.0 using $0.1 \mathrm{M} \mathrm{KOH}$. The closed, vertical photobioreactors were kept outdoors, and during the cultivation, temperature and solar radiation $\left(\mathrm{W} / \mathrm{m}^{2}\right)$ data were obtained from nearby meteorological stations (IAPAR 2014; Paraná 2014).

\section{Growth and biomass determinations}

A 50-mL aliquot was collected daily from the photobioreactor for the $\mathrm{OD}_{670}$ and dry biomass analyses that were performed as described in the growth chamber experiment. On day 10 of cultivation, the cell density was determined by counting cells with an improved Neubauer hemocytometer using an optical microscope (Eclipse E200, Nikon) with a $40 \times$ objective and a visual magnification of $400 \times$. Biomass productivity in $\mathrm{mg} \mathrm{L}^{-1} \mathrm{~d}^{-1}$ was calculated from the variations in biomass concentration (in $\mathrm{mg} \mathrm{L}^{-1}$ ) at different cultivation times (in $\mathrm{d}$ ) according to the following equation:

$$
p=x_{1}-x_{0} / t_{1}-t_{0}
$$

where $x_{1}$ and $x_{0}$ are the biomass concentrations (in $\mathrm{mg} \mathrm{L}^{-1}$ ) on $\mathrm{d} t_{1}$ and $t_{0}$, respectively.

The specific growth rate $\left(\mu \mathrm{d}^{-1}\right)$ was calculated as described previously (Kong et al. 2013; Li et al. 2014) using the following equation:

$$
\mu=\left(\ln x_{1}-\ln x_{0}\right) / t_{1}-t_{0}
$$

where $x_{1}$ and $x_{0}$ are the biomass concentrations (in $\mathrm{g} \mathrm{L}^{-1}$ ) on $\mathrm{d} t_{1}$ and $t_{0}$, respectively. 


\section{Lipid and protein contents}

On day 10 of cultivation, the biomass was harvested by concentrating the entire volume $(20 \mathrm{~L}$ ) by centrifugation in $250-\mathrm{mL}$ bottles at $25.0{ }^{\circ} \mathrm{C}$ at $2336 \mathrm{~g}$ for $20 \mathrm{~min}$. Then, the supernatant was transferred to Falcon tubes that were centrifuged at 11,536 g for $10 \mathrm{~min}$. Subsequently, the biomass was freeze-dried in a lyophilizer (LIOBRAZ L101 model) for lipid and protein content determinations. Total lipids were extracted from $100 \mathrm{mg}$ of lyophilized microalgal biomass using the method described by Bligh and Dyer (1959) and the procedure given by Ryckebosch et al. (2012). The lipids were extracted with chloroform, methanol, and water at a ratio 1:1:0.8. Total nitrogen $(\mathrm{N})$ was determined by the Kjeldahl micro-method using $100 \mathrm{mg}$ of lyophilized biomass (Bremner 1965). Total protein contents were calculated using the total $\mathrm{N}$ data and conversion factors of 6.25 , according to Alkhamis and Qin (2015), and 4.92, as recommend for green, brown, and red marine algae by Lourenço et al. (2002). All assays were conducted in triplicate.

\section{Nuclear magnetic resonance (NMR) analysis of FFAs}

The extract to lipid analysis was obtained with procedure used to determine the total lipid content described by Bligh and Dyer (1959) and modified by Ryckebosch et al. (2012). The lipid profile was obtained by NMR that was performed at the Multiuser Laboratory of Spectroscopy-SPEC-UEL, State University of Londrina, Londrina, Brazil,. The samples were dissolved in $\mathrm{CDCl}_{3}$ solvent and analyzed using a Bruker Avance III $400 \mathrm{MHz}$ spectrometer equipped with a $5 \mathrm{~mm}$ double resonance broadband inverse (BBI) probe at $303 \mathrm{~K}$. The ${ }^{1} \mathrm{H}$-NMR experiments were performed at $400.13 \mathrm{MHz}$ with the standard pulse sequences described by Braun and collaborators (2000). The FFA degree of total lipid was calculated from the area of the peaks obtained from deconvoluted spectrum using 50/50 Gaussian/Laurentzian; the $\alpha$-carbonyl methylene hydrogens were counted as six hydrogens, and $\mathrm{C} 1$ and $\mathrm{C} 3-\mathrm{CH}_{2}-\mathrm{O}$ - as four hydrogens, considering for $100 \%$ esterification (Carneiro et al. 2005).

\section{Results}

\section{Dry biomass}

In the first experiment, the initial inoculum had a concentration of $1.67 \times 10^{7}$ cells $\mathrm{mL}^{-1}$, a dry biomass concentration of $0.29 \mathrm{~g} \mathrm{~L}^{-1}$, an $\mathrm{OD}_{670}$ of 0.52 , and a $\mathrm{pH}$ of 8.70 . The variables studied had significant $(p<0.01)$ effects on the dry biomass of $N$. oleoabundans, and the highest value was $1.4 \mathrm{~g} \mathrm{~L}^{-1}$, which was obtained on day 10 of cultivation (Fig. 1a, b). The regression coefficient $\left(R^{2}=0.97\right)$ showed that $97 \%$ of the variability could be explained by the model and the best response prediction (Burkert et al. 2004; Safaralie et al. 2010). To confirm the validity and the model fit, an assessment of the experimental data was performed using analysis of variance, and the model
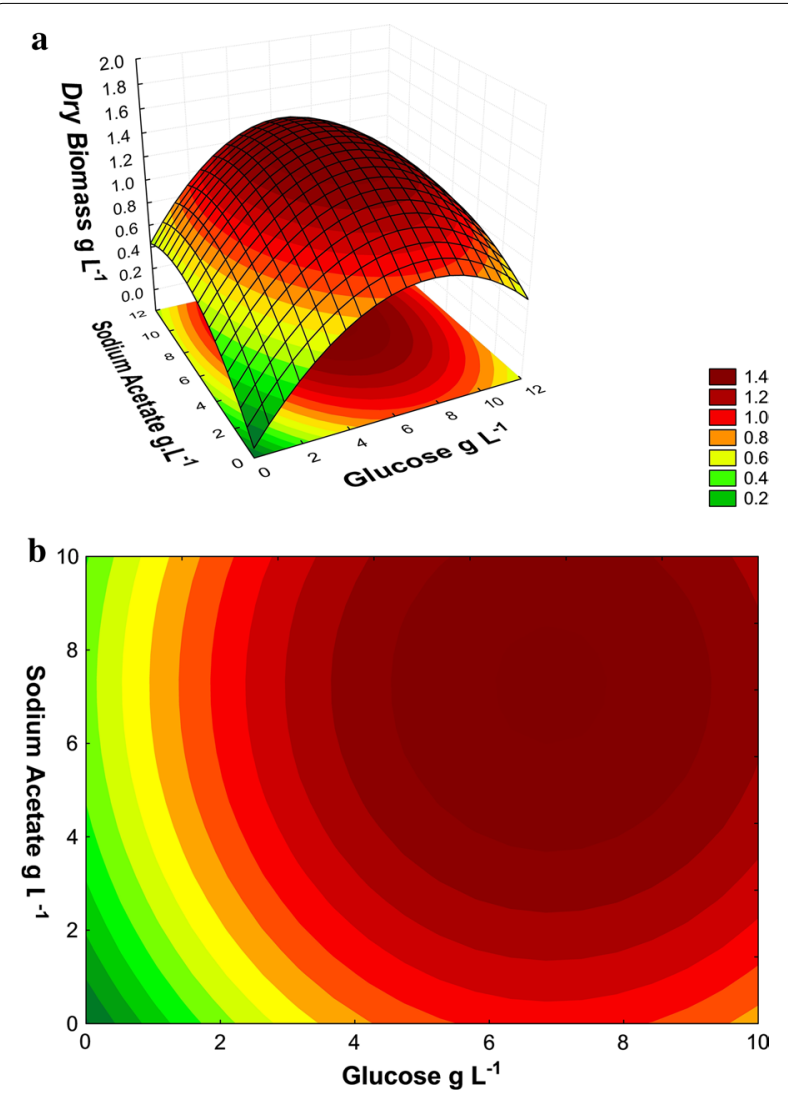

Fig. 1 Dry biomass $\left(\mathrm{g} \mathrm{L}^{-1}\right)$ of the N. oleoabundans on day 10 of cultivation in BBM (100\%). a Response surface and $\mathbf{b}$ curve contour, showing the interactions between the concentrations $\left(\mathrm{g} \mathrm{L}^{-1}\right)$ of the sodium acetate and glucose

presented a value of $p=0.20$ for the lack of fit, which is not significant, indicating that the model can be used for predictive purposes (Tovar et al. 2010). The response surface and contour curve (Fig. 1a, b) were obtained from the regression coefficient after analysis of the fitted model, as shown in the following equation:

$$
\begin{aligned}
z= & -1.254+0.266 x-0.017 x^{2}+0.097 y-0.009 y^{2} \\
& +1.05 \times 10^{4} \times\left(x y^{2}\right)-3.32 \times 10^{-4} \times\left(x^{2} y\right) \\
& -2.05 \times 10^{-6} \times\left(100 x^{2}\right)+5.78 \times 10^{-4} \\
& \times(100 y)+1.135
\end{aligned}
$$

The analysis of the means of dry biomass production $\left(\mathrm{g} \mathrm{L}^{-1}\right.$ ) assayed on $\mathrm{d} 10$ of cultivation was influenced by a combination of the concentrations of glucose and sodium acetate in the medium, as well as by the \% BBM (Fig. 1a). On day 15 of cultivation, the regression coefficient obtained was $R^{2}=0.98$. The analysis of variance indicated that the lack of fit $(p=0.15)$ was not significant, 
confirming the validity of the model. From the regression coefficient and model fit analysis, the response surface and contour curve were obtained as shown in Eq. (4):

$$
\begin{aligned}
z= & -1.006+0.157 x-0.006 x^{2}+0.089 y-0.006 y^{2} \\
& +0.005 x y+\left(4.656 \times 10^{-6} \times 10,000 x\right) \\
& -\left(8.841 \times 10^{-5} \times 100 x^{2}\right) \\
& -\left(1.490 \times 10^{-6} \times 10,000 y\right)+1.014
\end{aligned}
$$

In the response surface study, the \% BBM variable was kept at $100 \%$, and the results obtained were similar to those on day 10 of the cultivation (Fig. 2a, b). Thus, the microalgal biomass was influenced by different concentrations of glucose and sodium acetate.

\section{$\mathrm{OD}_{670}$ analysis}

$\mathrm{OD}_{670}$ analyses of microalgal cultures were performed on $\mathrm{d} 10$ and 15 . On d 10, the obtained regression coefficient was $R^{2}=0.99$, and the lack of fit of the experimental data

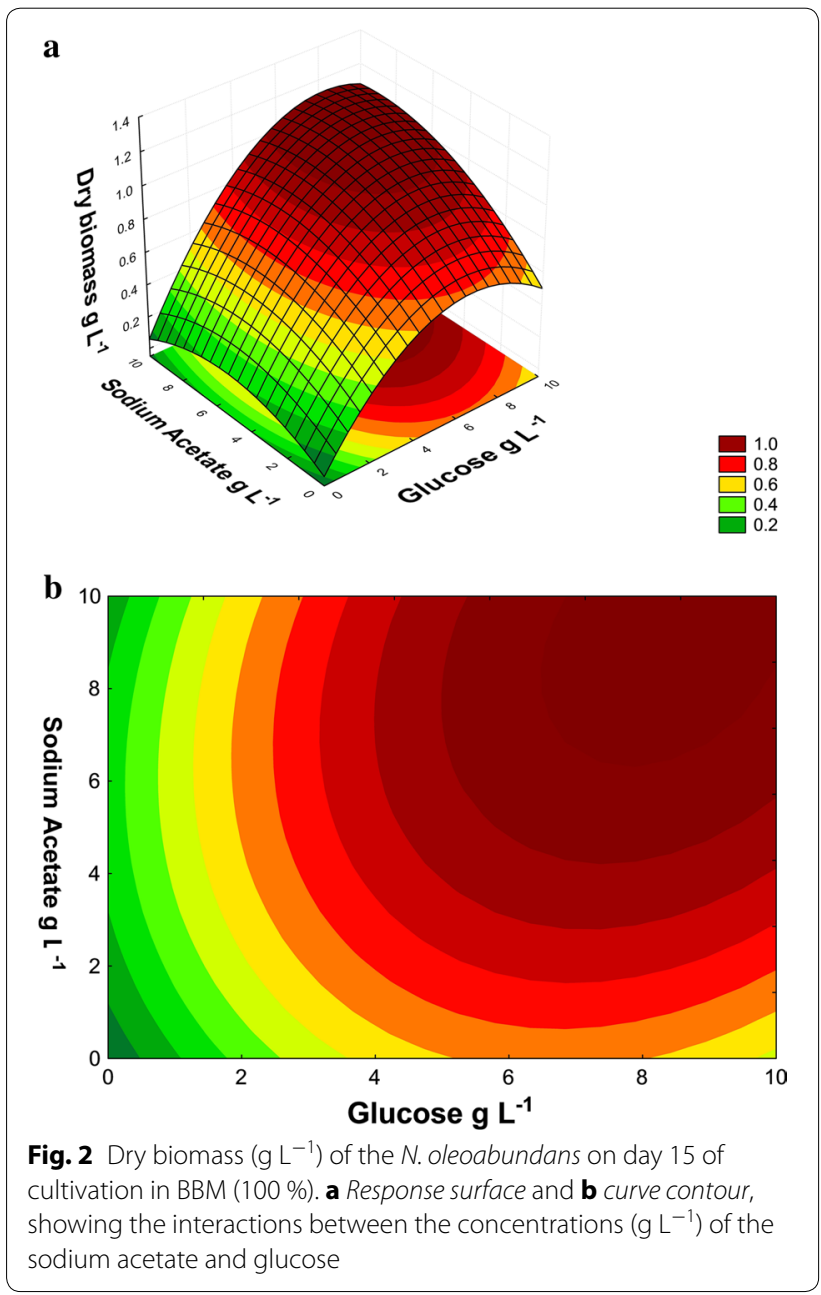

was verified by analysis of variance. The model presented a value of $p=0.55$, which is not significant, thus confirming the validity of the model. The response surface and contour curve are represented by the following equation:

$$
\begin{aligned}
z= & -0.154+0.063 x-0.002 x^{2}+0.069 y \\
& -0.006 y^{2}+0.036 x y-0.001 x y^{2} \\
& -0.001 x^{2} y+0.002 \times 87.5 x \\
& -\left(2.30 .10^{-4} 87.5 x^{2}\right)+0.3255
\end{aligned}
$$

An analysis of means based on the concentrations of glucose and sodium acetate in $100 \%$ BBM showed that the highest $\mathrm{OD}_{670}(2.0)$ was obtained when the glucose concentration ranged from 5 to $9 \mathrm{~g} \mathrm{~L}^{-1}$ and the sodium acetate concentration ranged from 4 to $10 \mathrm{~g} \mathrm{~L}^{-1}$ (Fig. 3a, b). These results demonstrate that there is a positive relationship between the $\mathrm{OD}_{670}$ and biomass production.

On day 15 of cultivation, the obtained regression coefficient was $R^{2}=0.97$, and the lack of fit of the experimental data was analyzed by analysis of variance. The model

$\mathbf{a}$
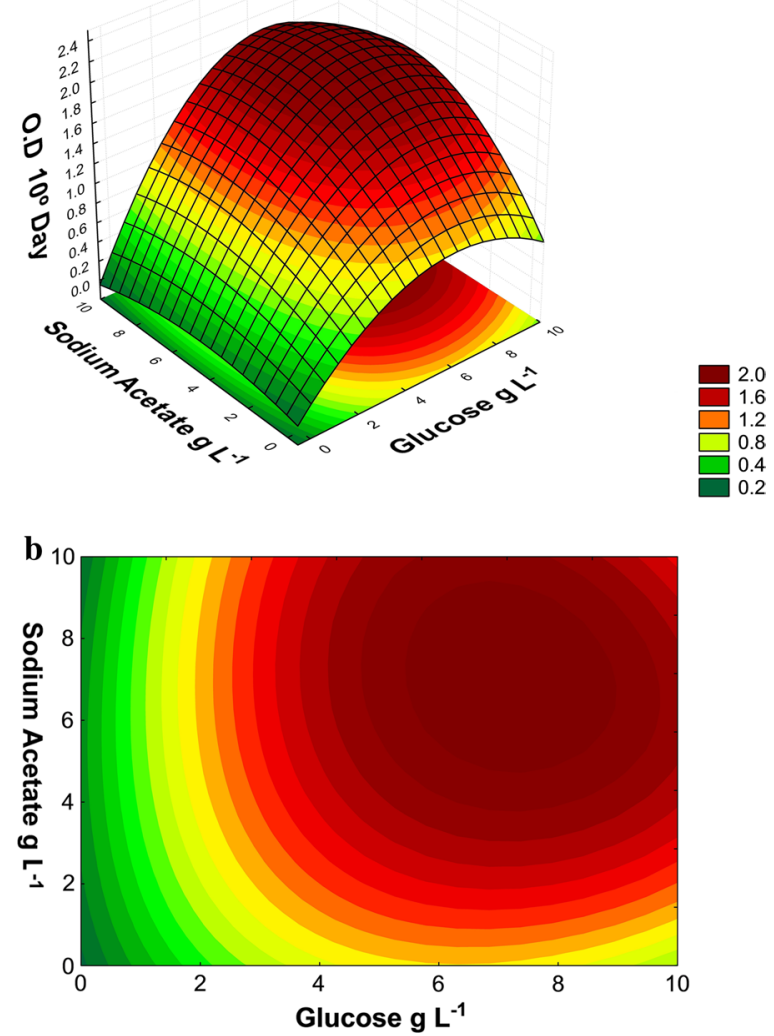

Fig. 3 Optical density $\left(\mathrm{OD}_{670}\right)$ of the $N$. oleoabundans on day 10 of cultivation in BBM (100\%). a Response surface and b curve contour, showing the interactions between the concentrations $\left(\mathrm{gL}^{-1}\right)$ of the sodium acetate and glucose 
presented a value of $p=0.41$, which is not significant, thus confirming the validity of the model. The response surface and contour curve are represented by Eq. (6):

$$
\begin{aligned}
z= & -1.233+0.264 x-0.019 x^{2}+0.232 y-0.018 y^{2} \\
& +0.025 x y-\left(8.5 \times 10^{-4} \times x y^{2}\right) \\
& -0.001 x^{2} y-0.001 \times 50 y \\
& +\left(1.308 \times 10^{-4} \times 50 y^{2}\right)+1.141
\end{aligned}
$$

The highest average $\mathrm{OD}_{670}, 1.6$, was obtained when the glucose concentration ranged from 5.0 to $9.0 \mathrm{~g} \mathrm{~L}^{-1}$ and the sodium acetate concentration ranged from 4.0 to $10.0 \mathrm{~g} \mathrm{~L}^{-1}$ in the BBM (Fig. 4a, b). According to Fig. 5a, $\mathrm{b}$, when working with a concentration of $7.5 \mathrm{~g} \mathrm{~L}^{-1}$ of sodium acetate and glucose, BBM dilution can be done, since above $60 \%$ are obtained an average $1.2 \mathrm{~g} \mathrm{~L}^{-1}$ of dry biomass on $\mathrm{d} 10$ of cultivation. The response surface and contour curve are represented by the following equation:
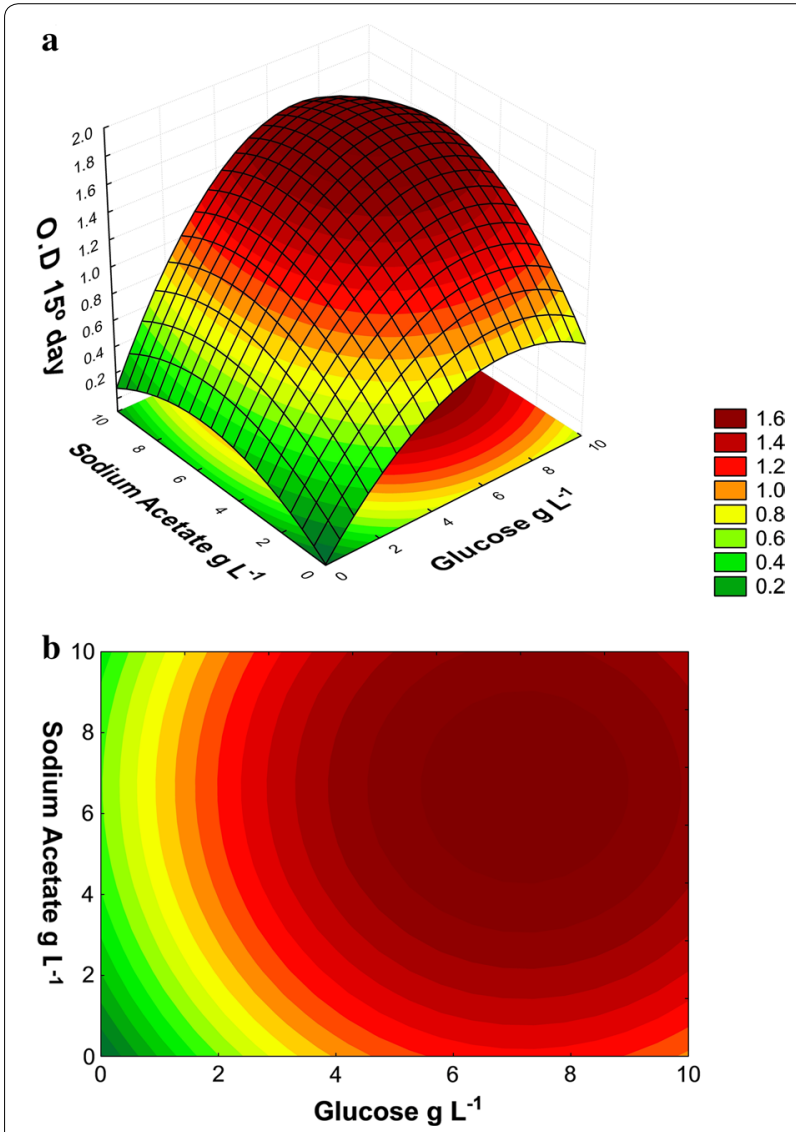

Fig. 4 Optical density $\left(\mathrm{OD}_{670}\right)$ of the N. oleoabundans on day 15 of cultivation in BBM (100\%). a Response surface and $\mathbf{b}$ contour curve showing the interactions between the concentrations $\left(\mathrm{g} \mathrm{L}^{-1}\right)$ of the acetate sodium and glucose a
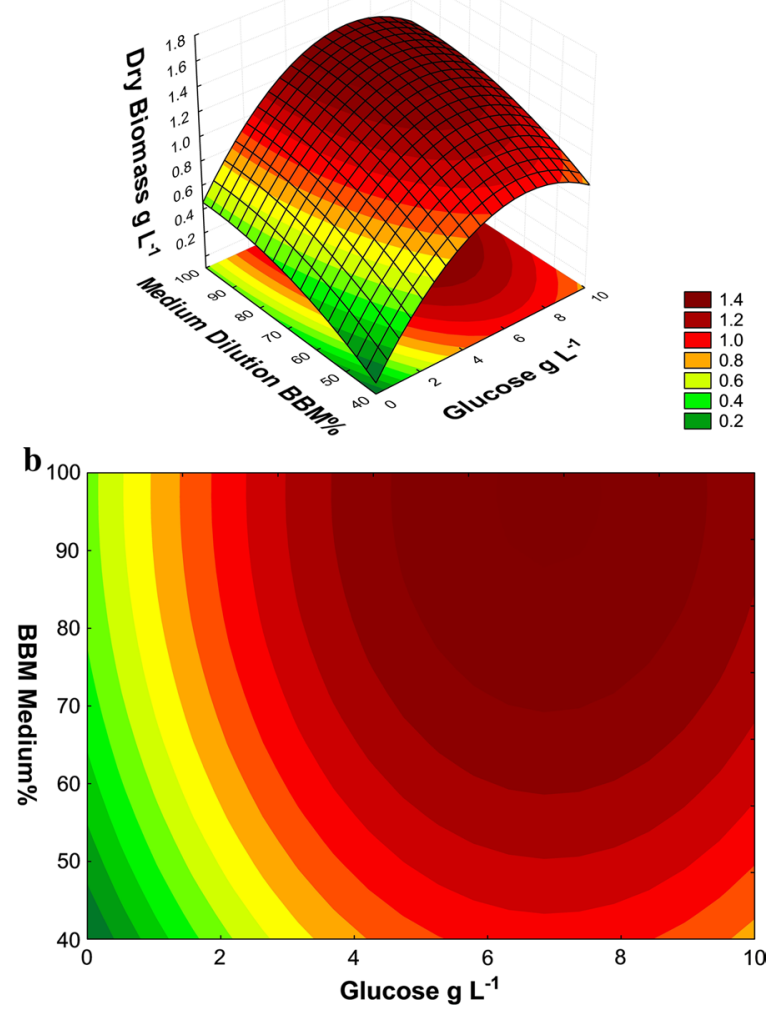

Fig. 5 Dry biomass $\left(\mathrm{g} \mathrm{L}^{-1}\right)$ of the $N$. oleoabundans on day 10 of cultivation in medium contained the concentration of $7.5 \mathrm{~g} \mathrm{~L}^{-1}$ of sodium acetate. $\mathbf{a}$ Response surface and $\mathbf{b}$ contour curve showing the interactions between the \% BBM and glucose concentration $\left(\mathrm{g} \mathrm{L}^{-1}\right)$

$$
\begin{aligned}
z= & -1.349+0.276 x-0.019 x^{2}+0.027 y \\
& -\left(1.395 \times 10^{-4} \times y^{2}\right)+0.474
\end{aligned}
$$

\section{Growth in outdoor photobioreactors}

To provide aeration and mixing in each photobioreactor without contaminating the growth media, air was flowed through a $0.22-\mu \mathrm{m}$ filter (Millipore) that was connected to an injection pump (FRISKAM ${ }^{\circledR}$ Super Model II) (Fig. 6a). The air temperature during the 10-day cultivation in the photobioreactor averaged $28.4{ }^{\circ} \mathrm{C}$, with a maximum of $31{ }^{\circ} \mathrm{C}$ and a minimum of $21.5^{\circ} \mathrm{C}$ (IAPAR 2014). The solar radiation recorded averaged $414.3 \mathrm{~W} / \mathrm{m}^{2}$, with a maximum of $563 \mathrm{~W} / \mathrm{m}^{2}$ and a minimum of $92.9 \mathrm{~W} / \mathrm{m}^{2}$ (Paraná 2014).

The initial inoculum had an $\mathrm{OD}_{670}$ of 0.14 , a concentration of $9.9 \times 10^{6}$ cells per $\mathrm{mL}$, a $\mathrm{pH}$ of 7.6 , and $0.03 \mathrm{~g} \mathrm{~L}^{-1}$ of dry biomass. The culture medium was based on the optimal concentrations determined in the first part of the this study, which were $7.5 \mathrm{~g} \mathrm{~L}^{-1}$ of glucose, $7.5 \mathrm{~g} \mathrm{~L}^{-1}$ of sodium acetate, and $100 \%$ BBM. The growth curve based 

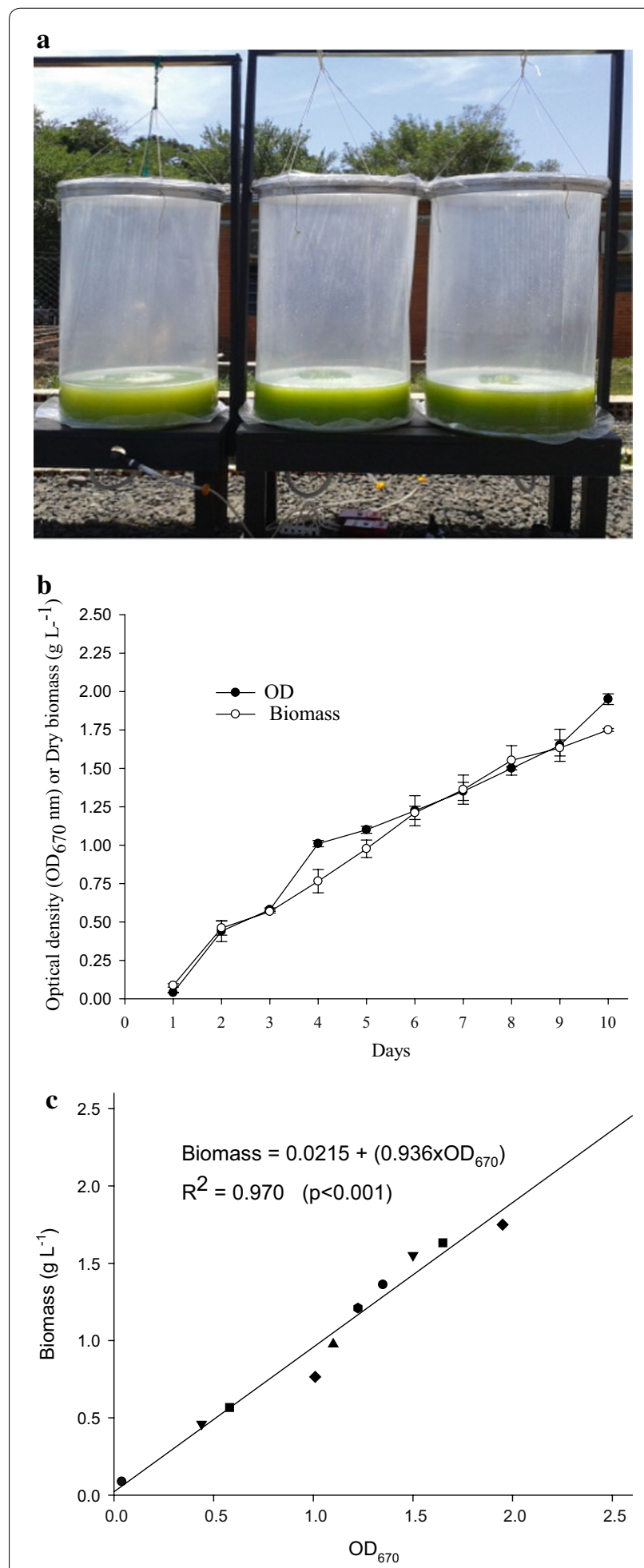

Fig. 6 a Vertical tubular photobioreactor low density polyethylene with air injection, $\mathbf{b}$ Growth curve of $N$. oleabundans: absorbance $\mathrm{OD}_{670}$ of the culture medium and dry biomass in $\mathrm{g} \mathrm{L}^{-1}$, $\mathbf{c}$ linear regression between biomass and optical density $\left(\mathrm{OD}_{670}\right)$. Bars represent standard deviations, $\mathrm{n}=3$ on the cell concentrations showed that there was a linear increase over the time period examined (Fig. 6b). The highest average $\mathrm{OD}_{670}(1.95 \pm 0.03)$ was observed on day 10 of cultivation.

The means of dry biomass in $\mathrm{g} \mathrm{L}^{-1}$ and their respective standard deviations during 10 day of cultivation of $N$. oleoabundans in the three photobioreactors are shown in Fig. 6b. The dry biomass production over the 10-day cultivation period linearly increased, with the lowest yield $\left(0.08 \pm 0.01 \mathrm{~g} \mathrm{~L}^{-1}\right)$ on $\mathrm{d} 1$ of cultivation. The highest mean dry biomass $\left(1.75 \pm 0.01 \mathrm{~g} \mathrm{~L}^{-1}\right)$ occurred on day 10 of cultivation.

Overall, the different measures of $N$. oleoabundans development in the photobioreactors show that growth occurred as expected, because our system conditions only provide sunlight and a low amount of $\mathrm{CO}_{2}$ from the air. The number of cells averaged $8.06 \times 10^{7}$ cells $\mathrm{mL}^{-1}$. The specific growth rate $(\mu)$ was $0.145 \mathrm{~d}^{-1}$. There was a linear relationship $\left[\mathrm{g} \mathrm{L}^{-1}\right.$ biomass $\left.=0.0215+\left(0.936 \times \mathrm{OD}_{670}\right)\right]$ between the $\mathrm{OD}_{670}$ and the biomass, in terms of the dry cell weight, with a correlation coefficient of $\mathrm{R}^{2}=0.970$ $(p<0.001)$, which passed $(p=0.388)$ the Shapiro-Wilk normality test (Fig. 6c).

An analysis of the lyophilized biomass showed that under mixotrophic conditions, the average composition of $N$. oleoabundans biomass was $4.88 \pm 0.09 \% \mathrm{~N}$, $24.01 \pm 0.29-30.5 \pm 0.38 \%$ protein, and $34.4 \% \pm 0.81$ lipids (Table 3 ).

The NMR spectrum showed clearly all signals expected for triacyglycerol according to Carneiro et al. (2005), and signals between 4.10 and $4.35 \mathrm{ppm}$ that corresponds to $-\mathrm{CH}_{2}-\mathrm{O}-$, which is typical for $\mathrm{C} 1$ and $\mathrm{C} 3$ of fatty acidesterified glycerol (Fig. 7, insert). Regarding the lipid

Table 3 Cell count (cells $\mathrm{mL}^{-1}$ ), dry biomass production $\left(\mathrm{g} \mathrm{L}^{-1}\right)$ and productivity, total nitrogen $(\mathrm{N})$, protein in dry matter, percentage of lipids, and Free fatty acid (FFA) of the N. Oleoabundans, growing in an outdoor vertical photobioreactors under mixotrophic conditions on day 10

\begin{tabular}{|c|c|}
\hline Characteristics & Means (SD) \\
\hline Cell count (cells mL $\mathrm{mL}^{-1}$ ) & $8.06 \times 10^{7} \pm 0.11$ \\
\hline Dry biomass production $\left(\mathrm{g} \mathrm{L}^{-1}\right)$ & $1.75 \pm 0.01$ \\
\hline Dry biomass productivity (mg $\mathrm{L}^{-1} \mathrm{~d}^{-1}$ ) & $184.81 \pm 0.05$ \\
\hline aTotal $\mathrm{N}$ in biomass (\%) & $4.88 \pm 0.09$ \\
\hline bprotein in biomass (\%) & $30.5 \pm 0.38$ \\
\hline 'Protein in biomass (\%) & $24.01 \pm 0.29$ \\
\hline Lipid in the biomass (\%) & $34.7 \pm 0.81$ \\
\hline Free fatty acid (\%) & $11.25 \%$ \\
\hline
\end{tabular}

a Kjeldal determination; ${ }^{b, c}$ calculated with factors 6.25 and 4.92, respectively. Data are means of three replicates \pm standard deviation (SD) 


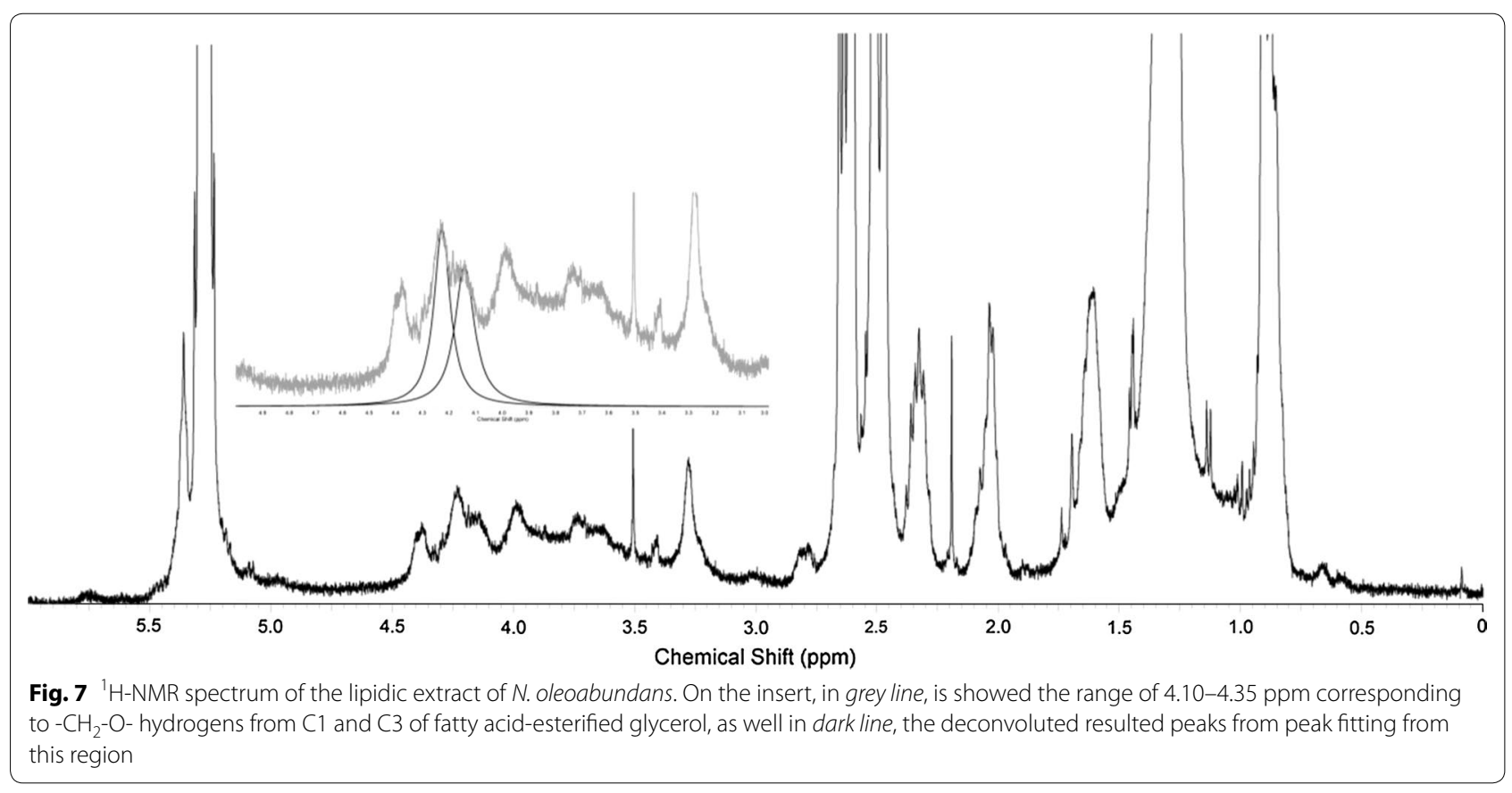

profile of $N$. oleoabundans growing outdoors in a mixotrophic culture medium with optimum glucose and sodium acetate levels, the percent of FFA content was $11.25 \%$ as measured by ${ }^{1} \mathrm{H}-\mathrm{NMR}$ (Table 3 ).

\section{Discussion}

$N$. oleoabundans yielded a maximum $\mathrm{OD}_{670}$ of 2.0 and a dry biomass concentration of $1.4 \mathrm{~g} \mathrm{~L}^{-1}$ when grown at optimal levels of the factors that were obtained using a response surface methodology analysis (100 \% BBM plus $7.5 \mathrm{~g} \mathrm{~L}^{-1}$ each of glucose and sodium acetate). The Chlorophyta N. oleoabundans (syn. Ettlia oleoabundans) (Sphaeropleales, Neochloridaceae) strain UTEX\#1185, which was isolated from Saudi Arabian sand dunes, is considered to be a halotolerant strain that thrives under phototrophic and heterotrophic conditions. Therefore, this green microalgal strain was chosen for our study because of its strong tolerance to high alkalinity and salinity and, as a oleaginous microalga, it is known to produce high levels of lipids (Gouveia and Oliveira 2009), even when grown under mixotrophic conditions (Baldisserotto et al. 2014).

\section{Dry biomass production and $\mathrm{OD}_{670}$}

Increasing the glucose concentration from 5.0 to $9.0 \mathrm{~g} \mathrm{~L}^{-1}$ and the sodium acetate concentration from 4.0 to $10.0 \mathrm{~g} \mathrm{~L}^{-1}$ increased the dry biomass production of $N$. oleoabundans to $1.4 \mathrm{~g} \mathrm{~L}^{-1}$. As there was interaction between these two factors, it was necessary to add both carbon sources to maximize the biomass production.
Similarly, Kong et al. (2013) reported that there was a significant interaction between glycerol and glucose on the production and biochemical composition of biomass after $C$. vulgaris was cultivated under mixotrophic conditions for $96 \mathrm{~h}$. Prior to exploring the effects of combinations of glucose and sodium acetate on $N$. oleoabundans growth, we investigated the use of glycerol in mixotrophic cultures, and showed that growth was inhibited after 4 days. This may have resulted from a rapid decrease in the $\mathrm{pH}$ of the medium, which resulted in enormous numbers of dead cells.

It was evident from the dry biomass and $\mathrm{OD}_{670}$ data that the best results were achieved on day 10 , rather than on day 15 , of cultivation. Thus, we chose to optimize a 10-day period of cultivation in an outdoor, vertical photobioreactor. On day 10 of cultivation, the optimum concentrations of sodium acetate and glucose for dry biomass production were both $7.5 \mathrm{~g} \mathrm{~L}^{-1}$. With the response surface analysis, we illustrated the similarity between the $\mathrm{OD}_{670}$ and the production of biomass $\left(\mathrm{g} \mathrm{L}^{-1}\right)$. However, the optimum \% BBM varied, as shown in Fig. 5a, b. In our study, the Box-Behnken experimental design was proven to be a good tool with which to examine microalgal growth and lipid productivity, as was demonstrated previously (Burkert et al. 2004; Ghosh et al. 2015).

\section{Microalgal growth in photobioreactors}

Given the difficulty in keeping outdoor photobioreactors sterilized, the cell count was used to assess the level of contamination, and the lack of a high number 
of contaminants was probably due to the alkalinity of the medium, as it was maintained at $\mathrm{pH} 9.0$ during the growth period. The biomass productivity of the outdoor, vertical photobioreactor culture of $N$. oleoabundans was $1.75 \mathrm{~g} \mathrm{~L}^{-1}$. We found that medium with a glucose concentration of $7.5 \mathrm{~g} \mathrm{~L}^{-1}$ was ideal for achieving the highest cell biomass accumulation in a mixotrophic culture of $N$. oleoabundans.

This low biomass value may be due to FFAs and substances derived from the oxidation of unsaturated fatty acids. According to Sabia et al. (2015), these compounds are metabolites that have inhibitory effects on microalgae, and they influence the production of biomass in mixotrophic culture media. We found that the N. oleoabundans yield coefficient based on the glucose concentration was only $23 \%$ when calculated using the highest biomass productivity $\left(1.75 \mathrm{~g} \mathrm{~L}^{-1}\right)$ divided by glucose concentration $\left(7.5 \mathrm{~g} \mathrm{~L}^{-1}\right)$. In fact, it should be less than $23 \%$, as $\mathrm{CO}_{2}$ production via photosynthesis also contributed to the cell biomass. Under mixotrophic conditions it was demonstrated that $N$. oculata CCMP $525, D$. salina FACHB 435, and C. sorokiniana CCTCC M209220 had different ability to use glucose, which ranged from $27 \pm 1$ to $93 \pm 6 \%$ according to glucose concentrations in the medium (Wan et al. 2011).

The effects of carbon supplementation were also studied by Giovanardi et al. (2014), who observed that a lower concentration of glucose $\left(2.5 \mathrm{~g} \mathrm{~L}^{-1}\right)$ was optimal for boosting the cell density and lipid accumulation in the biomass of $N$. oleoabundans UTEX\#1185. These authors also concluded that the growth of this microalga was limited when the glucose concentration was greater than $10.0 \mathrm{~g} \mathrm{~L}^{-1}$. Studies of different microalgae also have showed varied responses to glucose or sodium acetate. For example, maximum biomass production $\left(2.01 \mathrm{~g} \mathrm{~L}^{-1}\right)$ by Phaeodactylum tricornutum UTEX\#640 was achieved at a glucose concentration of $5.0 \mathrm{~g} \mathrm{~L}^{-1}$, while a sodium acetate concentration of $4.1 \mathrm{~g} \mathrm{~L}^{-1}$ yielded $1.15 \mathrm{~g} \mathrm{~L}^{-1}$ of biomass (Garcia et al. 2005). For Chlamydomonas reinhardtii, it was shown that a higher sodium acetate concentration $\left(10 \mathrm{~g} \mathrm{~L}^{-1}\right)$ was needed to produce $2.15 \mathrm{~g} \mathrm{~L}^{-1}$ of dry biomass (Moon et al. 2013).

The specific growth rate $(\mu)$ of $N$. oleoabundans was $0.145 \mathrm{~d}^{-1}$, without any additional light besides an average solar radiation of $414.3 \mathrm{~W} / \mathrm{m}^{2}$. This specific growth rate was lower than that reported by Kong et al. (2013) for $C$. vulgaris grown in medium containing glycerol and glucose at $30{ }^{\circ} \mathrm{C}$ and an illumination of 2500 lux. The lower growth rate in our study may have been due to the experimental conditions, in which the vertical photobioreactor containing $20 \mathrm{~L}$ of medium was placed outdoors, where there was a low light intensity and the minimum nighttime temperature was $21.5^{\circ} \mathrm{C}$. A significant finding by Li and co-workers (2014) was that mixotrophic green microalgae showed evidence of improved specific growth rates with increasing light intensities.

The protein content in N. oleoabundans biomass ranges from 44 (Morales-Sanchez et al. 2013) to $45 \%$ (Gatenby et al. 2003), showing that the protein content depends upon the growth conditions and the $\mathrm{N}$ factor that is used in the calculations. By comparing mixotrophic and phototrophic conditions, Alkhamis and Qin 2015 showed that there was a 2.5 -fold increase in the protein content of biomass when the marine microalga Tisochrysis lutea was grown under mixotrophic conditions, compared with that obtained during growth under phototrophic conditions.

We observed that the lipid content of $N$. oleoabundans cells was similar to that reported by Li et al. (2008), who also observed a $34 \%$ lipid content for this strain. Growth of $N$. oleoabundans UTEX\#1185 is highly promoted during the first week of mixotrophic cultivation, while photosynthetic pigments and lipids are over-produced during the following 3 weeks (Baldisserotto et al. 2014).

The ${ }^{1} \mathrm{H}$-NMR spectrum can be interpreted by comparing the ratio between the glycerol/methylene signals, as shown by Carneiro et al. (2005) but differently from these authors, that assign to the sum of the peak area the amount of four hydrogens to the glycerol comparing with all other integrated peaks, the integration was compared with $\alpha$-carbonyl methylene hydrogens (2.2-2.35 ppm) that doesn't vary regardless the amount of FFA. A ${ }^{1} \mathrm{H}-$ NMR spectrum revealed that the FFA content of $N$. oleoabundans lipid fractions was $11.25 \%$. This value is lower than the values observed by other authors for different algal genera. When considering biofuel production from microalgal feedstocks, the FFA analysis is an important step, because although the extracted oils from microalgal biomass have been generally been show to contain high FFA contents of up to $19 \%$ of dry biomass, the saponifiable lipids and resulting biodiesel represent only $1 \%$ of the dry weight (Krohn et al. 2011). By comparing the growth of the marine microalga T. lutea, Alkhamis and Qin 2015 observed that the addition of $50 \mathrm{mM}$ glycerol as an organic carbon source to a mixotrophic culture changed the fatty acid profile and increased the overall algal biomass production. Biomass storage conditions can result in lipid degradation, which results in the release of volatile organic acids and/or the formation of FFAs (Foree and McCarty 1970). Chen et al. (2012) concluded that the lipid composition of wet algal biomass is modified during storage, and that high amounts of FFAs are produced by triacylglycerol hydrolysis at temperatures above the freezing point.

In conclusion, the Box-Behnken design is an effective tool by which to optimize the concentrations of glucose and sodium acetate to maximize biomass, lipid, 
and protein productivity by $N$. oleoabundans. This study also showed that optimizing the concentrations of glucose and sodium acetate when growing $N$. oleoabundans under mixotrophic conditions in a scaled-up photobioreactor can be used to generate biomass that is rich in proteins and that also has a high lipid content, which makes it a great potential feedstock for biofuel production.

\section{Authors' contributions}

HRS, CECP and DSA did the experimental design and manuscript writing. HRS, FZG and VHM performed microalga growth and all other analyse. HRS and CAT performed ${ }^{1} \mathrm{H}$-NMR experiment. All authors read and approved the final manuscript.

\section{Author details}

1 Dept of Agronomy, Universidade Estadual de Londrina, Londrina, Paraná 86051900, Brazil. ${ }^{2}$ Dept of Biotechnology, Universidade Estadual de Londrina, Londrina, Paraná 86051990, Brazil. ${ }^{3}$ College of Chemistry, Universidade Norte do Paraná, Londrina, Paraná 86041120, Brazil. ${ }^{4}$ Instituto Agronômico do Paraná, CP 480, Londrina, Paraná 86.047-902, Brazil.

\section{Acknowledgements}

The authors H. R. da Silva and F. Z. Gavilanes acknowledge PhD fellowships from National Council for the Improvement of Higher Education (CAPES). D. S. Andrade acknowledges Fundação Araucaria (grant 42306/2014). Institute Agronomic do Paraná (IAPAR) and Companhia Paranaense de Energia (Copel) had a bilateral collaboration Project of Microalga for Bioenergy that partial financially supported this study. We also thanks to Funding Authority for Studies and Projects (FINEP) for financial funds to implement the Multiuser Spectroscopy Platform (SPEC-UEL).

\section{Competing interests}

The authors declare that they no competing interests.

Received: 4 December 2015 Accepted: 14 January 2016

Published online: 05 February 2016

\section{References}

Alencar ERd, Faroni LRD, Peternelli LA, Silva MTCd, Costa AR. Influence of soybean storage conditions on crude oil quality. Revista Brasileira de Engenharia Agrícola e Ambiental. 2010;14:303-8.

Alkhamis Y, Qin JG. Comparison of pigment and proximate compositions of Tisochrysis /utea in phototrophic and mixotrophic cultures. J Appl Phycol. 2015. doi:10.1007/s10811-015-0599-0.

Amaro HM, Guedes AC, Malcata FX. Advances and perspectives in using microalgae to produce biodiesel. Appl Energy. 2011;88(10):3402-10. doi:10.1016/j.apenergy.2010.12.014.

Babuskin S, Radhakrishnan K, Babu PAS, Sivarajan M, Sukumar M. Effect of photoperiod, light intensity and carbon sources on biomass and lipid productivities of Isochrysis galbana. Biotechnol Lett. 2014;36(8):1653-60. doi:10.1007/s10529-014-1517-2.

Baldisserotto C, Giovanardi M, Ferroni L, Pancaldi S. Growth, morphology and photosynthetic responses of Neochloris oleoabundans during cultivation in a mixotrophic brackish medium and subsequent starvation. Acta Physiologiae Plantarum. 2014;36(2):461-72. doi:10.1007/s11738-013-1426-3.

Bligh EG, Dyer WJ. A rapid method of total lipid extraction and purification. Can J Biochem Physiol. 1959;37:911-7.

Bold HC. The morphology of Chlamydomonas chlamydogama sp. nov. Bull Torrey Bot Club. 1949;76(2):101-8.

Braun S, Kalinowski H-O, Berger S. 150 and more basic NMR experiments: a practical course second expanded edition. Weinheim: Wiley-VCH; 2000.

Bremner JM. Total nitrogen. In: Black CA, editor. Methods of soil analysis. Madison: Am Soc Agronomy; 1965. p. 1149-78.

Burkert JFM, Maugeri F, Rodrigues MI. Optimization of extracellular lipase production by Geotrichum sp using factorial design. Bioresour Technol. 2004;91(1):77-84. doi:10.1016/s0960-8524(03)00152-4.
Carneiro PIB, Reda SY, Carneiro EBB. ${ }^{1} \mathrm{H}$ NMR characterization of seed oils from rangpur lime (Citrus limonia) and "Sicilian" lemon (Citrus limon). Ann Magn Reson. 2005;4(3):64-8.

Chen L, Liu T, Zhang W, Chen X, Wang J. Biodiesel production from algae oil high in free fatty acids by two-step catalytic conversion. Bioresour Technol. 2012;111:208-14. doi:10.1016/j.biortech.2012.02.033.

Estévez-Landazábal L-L, Barajas-Solano A-F, Barajas-Ferreira C, Kafarov V. Improvement of lipid productivity on Chlorella vulgaris using waste glyc erol and sodium acetate Ciencia. Tecnología y Futuro. 2013;5(2):113-26.

Foree EG, McCarty PL. Anaerobic decomposition of algae. Environ Sci Technol. 1970;4(10):842-9. doi:10.1021/es60045a005.

Garcia MCC, Mirón AS, Sevilla JMF, Grima EM, Camacho FG. Mixotrophic growth of the microalga Phaeodactylum tricornutum influence of different nitrogen and organic carbon sources on productivity and biomass composition. Process Biochem. 2005;40:297-305.

Gatenby C, Orcutt D, Kreeger D, Parker B, Jones V, Neves R. Biochemical composition of three algal species proposed as food for captive freshwater mussels. J Appl Phycol. 2003;15(1):1-11. doi:10.1023/a:1022929423011.

Georgianna DR, Mayfield SP. Exploiting diversity and synthetic biology for the production of algal biofuels. Nature. 2012;488(7411):329-35. doi:10.1038/ nature 11479

Ghosh S, Roy S, Das D. Improvement of biomass production by Chlorella sp. MJ 11/11 for use as a feedstock for biodiesel. Appl Biochem Biotechnol. 2015. doi:10.1007/s12010-015-1503-8.

Giovanardi M, Baldisserotto C, Ferroni L, Longoni P, Cella R, Pancaldi S. Growth and lipid synthesis promotion in mixotrophic Neochloris oleoabundans (Chlorophyta) cultivated with glucose. Protoplasma. 2014;251(1):115-25 doi:10.1007/s00709-013-0531-x.

Gouveia L, Oliveira AC. Microalgae as a raw material for biofuels production. J Ind Microbiol Biotechnol. 2009;36(2):269-74. doi:10.1007/ s10295-008-0495-6.

Huang G, Chen F, Wei D, Zhang X, Chen G. Biodiesel production by microalgal biotechnology. Appl Energy. 2010;87(1):38-46.

IAPAR. Instituto Agronomico do Paraná, Agrometerologia- Dados Diários de Londrina, vol. 2014. Londrina-PR: IAPAR; 2014.

Jeon Y-C, Cho C-W, Yun Y-S. Combined effects of light intensity and acetate concentration on the growth of unicellular microalga Haematococcus pluvialis. Enzyme and Microbial Technol. 2006;39(3):490-5. doi:10.1016/j. enzmictec.2005.12.021.

Kim KH, Choi IS, Kim HM, Wi SG, Bae H-J. Bioethanol production from the nutrient stress-induced microalga Chlorella vulgaris by enzymatic hydrolysis and immobilized yeast fermentation. Bioresour Technol. 2014;153:47-54. doi:10.1016/j.biortech.2013.11.059.

Kong W-B, Yang H, Cao Y-T, Song H, Hua S-F, Xia C-G. Effect of glycerol and glucose on the enhancement of biomass, lipid and soluble carbohydrate production by Chlorella vulgaris in mixotrophic culture. Food Technol Biotechnol. 2013;51(1):62-9.

Krohn BJ, McNeff CV, Yan B, Nowlan D. Production of algae-based biodiesel using the continuous catalytic Mcgyan ${ }^{\circledR}$ process. Bioresour Technol. 2011;102(1):94-100. doi:10.1016/j.biortech.2010.05.035.

Li T, Zheng Y, Yu L, Chen S. Mixotrophic cultivation of a Chlorella sorokiniana strain for enhanced biomass and lipid production. Biomass Bioenergy. 2014;66(1):204-13. doi:10.1016/j.biombioe.2014.04.010.

Li Y, Horsman M, Wang B, Wu N, Lan C. Effects of nitrogen sources on cell growth and lipid accumulation of green alga Neochloris oleoabundans. Appl Microbiol Biotechnol. 2008;81(4):629-36. doi:10.1007/ s00253-008-1681-1.

Lourenço SO, Barbarino E, De-Paula JC, Pereira LOdS, Marquez UML. Amino acid composition, protein content and calculation of nitrogen-toprotein conversion factors for 19 tropical seaweeds. Phycological Res. 2002;50(3):233-41. doi:10.1046/j.1440-1835.2002.00278.x.

Moon M, Kim CW, Park W-K, Yoo G, Choi Y-E, Yang J-W. Mixotrophic growth with acetate or volatile fatty acids maximizes growth and lipid production in Chlamydomonas reinhardtii. Algal Res. 2013;2(4):352-7. doi:10.1016/j.algal.2013.09.003.

Morales-Sanchez D, Tinoco-Valencia R, Kyndt J, Martinez A. Heterotrophic growth of Neochloris oleoabundans using glucose as a carbon source. Biotechnol Biofuels. 2013;6(1):100.

Pruvost J, Van Vooren G, Le Gouic B, Couzinet-Mossion A, Legrand J. Systematic investigation of biomass and lipid productivity by microalgae in photobioreactors for biodiesel application. Bioresour Technol. 2011;102(1):150-8. 
Rai MP, Nigam S, Sharma R. Response of growth and fatty acid compositions of Chlorella pyrenoidosa under mixotrophic cultivation with acetate and glycerol for bioenergy application. Biomass Bioenergy. 2013;58:251-7.

Ryckebosch E, Muylaert K, Foubert I. Optimization of an analytical procedure for extraction of lipids from microalgae. J Am Oil Chem Soc. 2012;89(2):189-98. doi:10.1007/s11746-011-1903-z.

Sabia A, Baldisserotto C, Biondi S, Marchesini R, Tedeschi P, Maietti A, Giovanardi M, Ferroni L, Pancaldi S. Re-cultivation of Neochloris oleoabundans in exhausted autotrophic and mixotrophic media: the potential role of polyamines and free fatty acids. Appl Microbiol Biotechnol. 2015; doi:10.1007/s00253-015-6908-3.

Safaralie A, Fatemi S, Salimi A. Experimental design on supercritical extraction of essential oil from valerian roots and study of optimal conditions. Food Bioprod Process. 2010;88(C2-3):312-8. doi:10.1016/j.fbp.2009.02.002.

Silva HR, Guedes CLB, Andrade DS (2014) Fotobiorreator tubular e vertical em polietileno de baixa densidade (PEBD) para o cultivo de microalgas. Brasil Patent,

Statsoft I. Statistica (data analysis software system). 7th edn. 2007.

Tecnologia e informaçoes ambientais: Condiçoes atuais Londrina. 2014. http:// www.simepar.br/. Accessed 5 Jan 2015.

Tovar LP, Maciel MRW, Pinto GMF, Maciel R, Gomes DR. Factorial design applied to concentrate bioactive component of Cymbopogon citratus essential oil using short path distillation. Chem Eng Res Des. 2010;88(2A):239-44. doi:10.1016/j.cherd.2009.07.018.
Wan M, Liu P, Xia J, Rosenberg J, Oyler G, Betenbaugh M, Nie Z, Qiu G. The effect of mixotrophy on microalgal growth, lipid content, and expression levels of three pathway genes in Chlorella sorokiniana. Appl Microbiol Biotechnol. 2011;91(3):835-44. doi:10.1007/s00253-011-3399-8.

Wang HY, Fu R, Pei GF. A study on lipid production of the mixotrophic microalgae Phaeodactylum tricornutum on various carbon sources. Afr J Microbiol Res. 2012;6(5):1041-7. doi:10.5897/ajmr11.1365.

Wieczorek N, Kucuker MA, Kuchta K. Fermentative hydrogen and methane production from microalgal biomass (Chlorella vulgaris) in a two-stage combined process. Appl Energy. 2014;132:108-17. doi:10.1016/j. apenergy.2014.07.003.

Yaakob Z, Ali E, Zainal A, Mohamad M, Takriff MS. An overview: biomolecules from microalgae for animal feed and aquaculture. J of Biol Res-Thessaloniki. 2014;21(1):1-10. doi:10.1186/2241-5793-21-6.

Yeesang C, Cheirsilp B. Low-cost production of green microalga Botryococcus braunii biomass with high lipid content through mixotrophic and photoautotrophic cultivation. Appl Biochem Biotechnol. 2014;174(1):116-29. doi:10.1007/s12010-014-1041-9.

Zhang H, Wang W, Li Y, Yang W, Shen G. Mixotrophic cultivation of Botryococcus braunii. Biomass Bioenergy. 2011;35(5):1710-5. doi:10.1016/j. biombioe.2011.01.002.

\section{Submit your manuscript to a SpringerOpen ${ }^{\circ}$ journal and benefit from:}

- Convenient online submission

- Rigorous peer review

- Immediate publication on acceptance

- Open access: articles freely available online

- High visibility within the field

- Retaining the copyright to your article

Submit your next manuscript at $>$ springeropen.com 